\title{
ANALYSIS OF THE POSSIBILITIES OF THE MOODLE LEARNING MANAGEMENT SYSTEM FOR ORGANIZATION OF DISTANCE LEARNING IN THE CONDITIONS OF THE UNIVERSITY
}

\section{S. Zelinskiy}

The modern world has changed dramatically with the widespread introduction of information and communication technologies. Today, an effective learning process without the use of modern technologies is unthinkable. Learning management systems are a bright representative of modern technologies, on the basis of which it is possible to organize the interaction of all participants in the learning process in the global Internet. The search for new approaches to the use of learning management systems can further enhance the effect of the use of modern information and communication technologies in the organization of the educational process.

The article gives a general description of the MOODLE training management system and the main elements of the course: questionnaire database; external tool; glossary; task; lecture; feedback; survey; SCORM package; seminar; test; forum; chat. Among the resources were identified: hyperlink; book; IMS content package; explanations; page; file. The practical use of the listed elements of the course of the MOODLE learning management system allows to fully implement distance learning and effective interaction between student and teacher.

The structure of the course includes the necessary set of structural elements (lectures, practical work, independent work, control of knowledge on the basis of tests) for the organization of distance learning in the conditions of higher educational institution.

A significant advantage of the introduction of MOODLE in the traditional educational process is that, without violating its course and principles, it greatly enriches it due to its rich information, communication and pedagogical capabilities. Distance learning with the help of MOODLE allows you to organize productive independent work of the student to master the discipline. Through the means of access to interactive learning elements and MOODLE resources, students have the opportunity to optimize the assimilation of educational material in preparation for classes, and with the help of control elements - to improve the quality of self-control

Keywords: professional training, distance learning, learning management system, MOODLE, module, course

Copyright (C) 2020, S. Zelinskiy. This is an open access article under the CC BY license (http://creativecommons.org/licenses/by/4.0).

\section{Introduction}

Today there are created technical preconditions for the wide use of distance learning in education, one of main problems of education development in this direction is elaboration and improvement of used information technologies.

In modern understanding distance learning is a process of acquiring knowledge at distance, based on using modern information and telecommunication technologies, without a personal contact between a teacher and students. At that the term e-learning is often used. The combination of traditional and distant forms is usually named blended learning [1].

The use of learning management systems (for example MOODLE) allows to systematize learning information and to provide a high level of interaction between a teacher and a student. The wide spectrum of instrumental possibilities in the system of learning management allows to decrease a load on a teacher in the process of course creation and to give a student a multifunctional and interactive learning course.

Introduction of the MOODLE learning management system allows to completely create a multifunctional ground for distance learning organization under higher educational institution conditions.

\section{Literary review}

The modern information space includes a great number of different studies in the sphere of distance learning organization under HEI conditions, based on using means of modern information-communication technologies. Among main directions, there may be separated: use of distance technologies in learning; educational process organization using distance technologies; use of learning management systems MOODLE for distance learning under HEI conditions and so on. At the same time there is no united approach to distance learning organization by means of modern informationcommunication technologies under higher educational institution conditions. It conditions a necessity of scientific search in this direction.

The distance learning technology is a system of scientifically substantiated instructions, given for realization in educational practice in the distance learning system. At that a kernel of the distance learning technology must be the following interconnected elements: methods, means, learning forms (at realizing the set content of education).

Distance learning technologies allow to organize students' independent work at the new level: memorization of lectures, taking tasks, sending home and semester works to a teacher, testing, communication by e-mail, at forums and many other. Forums may be used as learning elements too [2].

The use of distance technologies in the process of independent preparation allows not wasting time during a lesson for elementary tasks, but concentrating on creative 
ones, developing not only subject, but also communicative and culturological competences. That is why it is expedient for students to use these technologies with such learning elements as lecture, test-training, self-control test, diagnostic test, creative test and so on.

At modern HEIs distance learning is usually realized by means of e-learning management systems, LMS. Today there are a great number of such systems, for example, BlackBoard, WebCT, Top-Class, Claroline, ILIAS, Desire2Learn, MOODLE [3]. But there are also native program contributions, such as "Prometheus", "Batisphere", "IntraKnowledge" and many others [4].

It is also necessary to note open educational resources and internet-repositories, used for academic purposes, created for providing teacher's work productivity within blended learning: GoConqr; ThingLink; Present.me. These platforms and resources must provide effective interactions between teachers and students under blended learning conditions [5]. At the same time learning management systems are more flexible and widespread, comparing with the mentioned platforms.

The main shortcoming of existing forms of distance learning is that they are mainly commercial products with rather high cost. At that foreign contributions usually need knowledge in foreign languages, and native program products are often inferior to foreign analogues by the level of given possibilities. In most leading HEIs of the country the base of the e-learning system is MOODLE use $[6,7]$. It is explained by the fact that this e-product doesn't yield to commercial ones by its possibilities, but spreads for free and is translated in tens of languages.

MOODLE (Modular Object-Oriented Dynamic Learning Environment) is a learning management system, in which all are at the same time potential teachers and pupils. This principle provides a new stage of interrelations, when a teacher must not only become a source of knowledge for students, but also direct them on the independent way of searching for information.

It allows all participants of the learning process to share ideas, to listen for others, to ask questions and to organize communication that, in its turn, favors the formation-development of independence and self-support. Undoubtedly, the support of the learning process by distance technologies forms in students skills of work in the global network Internet and, as a result of it, creative thinking. At that the personal responsibility grows, more time is devoted to self-control and assessment that allows to raise the quality of students' outclass independent work essentially [8].

The MOODLE system includes many methods and means, necessary for distance learning organization. It has a great set of course elements, among which the following ones may be separated: questionnaire; database; external tool; glossary; task; lecture; feedback; survey; SCORM package; seminar; test; forum; chat.

The module "Questionnaire" provides three types of questionnaires for assessing and stimulating learning in distant courses. A teacher may recommend them for collecting data that help him/her to cognize his/her students better and to think about learning effectiveness. Questionnaires contain previously put questions without correction. Teachers, who want to create own questionnaires, may use the course element "Feedback".

The module "Database" allows participants to create, to serve and to search for records from the totality. The structure of records is determined by a teacher through the number of fields. Field types include small flags, switches, dropping lists, menus, text zones, hyperlinks, images and components for downloading.

A teacher may allow to comment records. They may be also assessed by teachers or students (equal-right assessment). Points may be combined for forming a final mark, written in the marks journal.

Database has a lot of uses, such as:

- common collections of web-references, books, reviews of books, journal references, bibliographic lists and so on.

- reflection of created photos, posters by students, web-sites or verses for viewing and mutual commenting.

The learning element "Tasks" allows teachers to give communication tasks, to collect students' works, to assess them, to give comments. Students may send any digital content (file), such as Word-documents, e-tables, images, audio or video files. A teacher may expect from a student additionally or as an alternative to insert his/her response directly in the text redactor. "Task" may be used also for answering beyond the site in autonomous mode (for example, at creating art objects) without presenting in digital form.

At assessing a task, a teacher may give responses as comments, download files with a corrected student's answer or audio-response. Answers may be assessed by points of the assessment scale, destined for a user or by "advanced" methods, such as rubrics. The final mark is written in the marks journal.

The course element "Lecture" allows a teacher to present content or/and practical tasks (tests) in the interesting and flexible form. A teacher may use the linear scheme of a lecture, consisting of a series of learning pages or create a complicated scheme, including different ways or variants for a pupil. In any case for increasing active cooperation and control of understanding, teachers may use different questions, such as "Multiple choice", "For correspondence" and "Short answer". Depending on answer, chosen by a student, and strategy, developed by a teacher, students may transfer to another page, to return to the previous one or being redirected by absolutely another way.

Lectures may be used:

- for independent learning of a new topic; decisions;

- for scenarios or exercises in modeling/making

- for control, with different sets of questions.

The course element "Test" allows a teacher to create tests, consisting of questions of different types: Multiple choice, True/not true, For correspondence, Short answer, Numerical. It is possible to create a test with several attempts, with occasional questions, to search from the question bank. A time limitation may be given.

Each attempt is assessed automatically, excluding Ece questions, and a mark is written to the marks journal. It is possible to choose, are prompts, response and correct 
answers present or no, and when they are demonstrated to students.

Tests may be used:

- in course exams;

- as mini-tests for read tasks or at the end of a topic;

- in the final exam, using questions from intermediate ones;

- for providing an urgent response to a work;

- for self-assessment.

Among resources of the MOODLE learning management system, the following elements may be separated: hyperlink; book; IMS content package; explanation; page; file. The practice of using distance learning elements demonstrated the high effectiveness [9].

The module "Book" allows a teacher to create a multipage resource, similar to a book, with chapters. Books may contain media-files and also long text information, may be divided in sections.

Book may be used:

- for representing learning materials from separate sections;

- as a reference book;

- as a portfolio of examples of students' works.

The IMS content package is a set of files, packed according to the accepted standard and may be repeatedly used in different systems. The module "IMS content package" may be downloaded as an archive and added to a course as a resource.

Content is usually represented on several pages with navigation between them. There are different variants of content representation - in a floating window, with a navigation menu or buttons and so on. An IMS content package may be used for presenting multimedia content and animation.

The module "Page" allows a teacher to create a resource "web-page" by the text redactor. A page may represent a text, image, sound, video, web-reference, and implemented code, for example Google Maps.

Advantages of using the module "Page", instead of "File", make a resource more available (for example, for users of mobile devices). At big content volumes it is recommended to use Book instead of Page.

Page may be used:

- for presenting terms and conditions of a course or an abstract of a course program;

- for inserting different video or audio files in an explaining text.

The MOODLE system is designed, taking into account achievements of modern pedagogy, accented on cooperation with students, and may be used for both inclass and distance learning. Students may redact own personal profiles, add photos. All marks, received for performed tasks, may be collected on one page (or as a file). The complete report about user's entrance to the system and about the work with different modules is available. It is possible to set up e-mail delivery (news, forums, teachers' marks and comments).

At the wide spectrum of possibilities and elements, the MOODLE learning management system has the following functions: integrating, adapting, upbringing, developing, educational, reflexive, controlling [10]. Let's consider them more detail.
MOODLE has an integrating function. Due to its structure, the system gives a possibility to divide a learningupbringing course in modules and to integrate elements of other disciplines that favor the development of spiritual and esthetic qualities (descriptive art, literature, native language, history, music) in them. A teacher also may add the educational process by extralinguistic and culturological content through external internet-resources.

An adapting function of the system is manifested in creating a separate upbringing trajectory for a group of students, related to their interests, psychological peculiarities, language mastering level. All this favors the maximal simplification of comprehending a new learning course by all students, not depending on their individual peculiarities and knowledge level.

Undoubtedly, the main MOODLE function is an educational one. Distance learning allows concentrating attention on the process of studying a discipline and putting a student in conditions of using knowledge for widening own mental outlook.

An upbringing function is connected with themes of learning-upbringing materials and tasks. Under conditions of moral-esthetic upbringing, a distance course is constructed mainly for an upbringing impact on a student.

A developing function is realized by influencing the student's emotional sphere by acquainting him/her with examples of culture and art. This function is realized mainly by creative tasks and expression of an independent point of view.

A reflexive function is self-analysis and selfcriticism. Discussion of a problem question doesn't give a possibility to consider own judgment as a single possible and best. A course program is made, taking into account conduction of own content for each studying person, where he/she may trace own progress, self-education and mental outlook widening.

A controlling function is manifested in the possibility of teacher's control over students' work and putting marks for tasks realization and participation in discussions. A teacher may establish terms for task realization that makes work in the educational environment the same obligatory as one with other learning materials (textbooks, notebooks and so on).

\section{Research aim and tasks}

The aim of the article is to study possibilities of the MOODLE learning management systems for distance learning organization under conditions of higher educational institution.

The following tasks were set for attaining this aim:

1. To establish the necessity of distance learning under HEI conditions;

2. To describe key modules and functions of MOODLE;

3. To describe the course structure for distance learning organization under HEI conditions, based on the MOODLE learning management system.

\section{Materials and methods}

The MOODLE learning management system, freely accessible, was used in the research process. The course, including the wide spectrum of functional possibilities of the learning management system, was developed. 
Using the wide set of MOODLE resources and elements, a teacher gets the possibility to fill his/her course with interesting, cognitive modern materials, presenting them in a proper form.

Students, in their turn, get free access to new interactive methods of learning foreign languages. Due to the easiness of course redaction, a teacher may add and diversify it with different elements, complicate or facilitate if necessary. The easiness of course administration allows a teacher simply to register new users and also to publish information and news about the course.

The wide spectrum of MOODLE communication means allows students to be in constant connection with a teacher. A MOODLE advantage is the possibility of automatic assessment of students' works by it that favors objectivization of their training level assessment.

The means of processing and analysis of students' works allow a teacher to introduce necessary corrections in the learning course, adapting it to students' needs.

\section{Research results and their discussion}

At analyzing sources, it has been revealed, that the use of MOODLE at learning widens possibilities of the educational process in both in-class and independent students' work organization, forms of intermediate and summary control, gives the additional means for educational quality management, takes HEI learning at the new level.

It has been established, that the most effective structure of a typical course must include the following elements: lectures; practical works; independent works; control of knowledge by tests.

The work may be continued in studying the problem of content filling of distance learning, improvement of programs of author problem thematic courses, use of blended learning technologies.

\section{Conclusions}

So, the problem of distance learning organization under HEI conditions, based on the use of the MOODLE learning management system is rather urgent. The study of urgent problems of distance learning organization under HEI conditions allowed to make the following conclusions:

1. After analyzing the modern condition of the education system, the necessity of distance learning organization under HEI conditions, based on the use of the MOODLE learning management system, has been established.

2. It has been established, that a learning management system is a program addition for administering a learning course within distance learning. Having studied the MOODLE learning management system, the key modules were separated, among them: questionnaire; database; task; lecture; IMS package; test; page.

3. Having studied the possibilities and key modules of the MOODLE learning management system, the optimal structure of a typical course that must include the following elements: lectures; practical works independent works, control of knowledge by tests, was established.

\section{References}

1. Starichenko, B. E., Semenova, I. N., Slepukhin, A. V. (2015). Concering the interrelation of e-learning concepts in higher education. The Education and Science Journal, 9, 51-68. doi: http://doi.org/10.17853/1994-5639-2014-9-51-68

2. Zaitseva, O. N. (2012). Ispolzovanie LMS Moodle v obrazovanii. Obuchenie i vospitanie: metodiki i praktika, 2. Available at: https://cyberleninka.ru/article/n/ispolzovanie-lms-moodle-v-obrazovanii Last accessed: 13.07.2020

3. Mullagaliev, N. A., Urazlina, R. V. (2017). Ob otnoshenii studentov k vvedeniiu elementov distantsionnogo obucheniia v vuze. Innovatsionnaia nauka, 1-1, 188-191. Available at: https://cyberleninka.ru/article/n/ob-otnoshenii-studentov-k-vvedeniyuelementov-distantsionnogo-obucheniya-v-vuze Last accessed: 15.07.2020

4. Shurygin, V. Iu. (2016). O vozmozhnosti ispolzovaniia vuzovskikh elektronnykh obrazovatelnykh kursov v protsesse prepodavaniia fiziki $v$ shkole. Fizika v shkole, 4, 57-60.

5. Shaikina, O. I. (2016). Otkrytye obrazovatelnye resursy na osnove smeshannogo obucheniia v Tomskom politekhnicheskom universitete. Azimut nauchnykh issledovanii: pedagogika i psikhologiia, 5 (1 (14)), 134-136.

6. Kartuzova, T. V., Merlina, N. I., Seliverstova, L. V. (2016). Ispolzovanie nekotorykh elementov sistemy MOODLE v rabote so studentami zaochnogo otdeleniia pri izuchenii matematicheskikh distsiplin. Karelskii nauchnii zhurnal, 5 (2 (15)), 34-36.

7. Kravchenko, G. V. (2013). Ispolzovanie distantsionnoi sredy Moodle v obrazovatelnom protsesse studentov dnevnoi formy obucheniia. Izvestiia Altaiskogo gosudarstvennogo universiteta, 2 (78), 23-25.

8. Granitov, V. M., Nikulina, M. A., Bobrovskii, E. A. (2013). Ispolzovanie platformy Moodle dlia distantsionnogo obucheniia na kafedre infektsionnykh boleznei. Infektsionnye bolezni: Novosti. Mneniia. Obuchenie, 1 (2). Available at: https://cyberleninka.ru/article/n/ispolzovanie-platformy-moodle-dlya-distantsionnogo-obucheniya-na-kafedre-infektsionnyh-bolezney Last accessed: 13.07 .2020

9. Lobanov, Iu. Ia., Sharonova, A. V., Mironova, O. V., Moskalenko, I. S., Shulgov, Iu. I. (2018). Ispolzovanie elementov distantsionnogo obucheniia v protsesse osvoeniia distsipliny «Elektivnye kursy po fizicheskoi kulture i sportu». Uchenye zapiski universiteta Lesgafta, 12 (166), 144-148. Available at: https://cyberleninka.ru/article/n/ispolzovanie-elementov-distantsionnogoobucheniya-v-protsesse-osvoeniya-distsipliny-elektivnye-kursy-po-fizicheskoy-kulture-i-sportu Last accessed: 13.07.2020

10. Bobunova, A. S. (2017). Vospitatelnye vozmozhnosti i funktsii virtualnoi obrazovatelnoi sredy Moodle v usloviiakh inoiazychnogo obrazovaniia shkolnikov. Kant, 3 (24). Available at: https://cyberleninka.ru/article/n/vospitatelnye-vozmozhnosti-ifunktsii-virtualnoy-obrazovatelnoy-sredy-moodle-v-usloviyah-inoyazychnogo-obrazovaniya-shkolnikov Last accessed: 15.07.2020

Received date 05.08.2020

Accepted date 14.09.2020

Published date 30.09.2020

Zelinskiy Sergei, PhD, Department of Applied Mathematics and Informatics, Kryvyi Rih State Pedagogical University, Haharyna ave., 54, Kryvyi Rih, Ukraine, 50086

E-mail: zvit-zss@ukr.net 